\title{
High production of GABA in Pyrus ussuriensis Maximowicz fruit extract by mixed fermentation of lactic acid bacteria
}

\author{
Ji-Yeon Choe ${ }^{1}$, Sam-Pin Lee ${ }^{1,2}$ \\ ${ }^{1}$ Department of Food Science and Technology, Keimyung University, Daegu 42601, Korea \\ ${ }^{2}$ The Center for Traditional Microorganism Resource, Keimyung University, Daegu 42601, Korea
}

산돌배 과실 추출물의 젖산균 혼합발효를 통한 고농도 GABA 생산

\author{
최지연 ${ }^{1} \cdot$ 이삼빈 ${ }^{1,2 *}$ \\ ${ }^{1}$ 계명대학교 식품가공학과, ${ }^{2}$ 계명대학교 TMR센터
}

\begin{abstract}
z-Aminobutyric acid (GABA) was produced by the sequential fermentation of the fruit extract of Pyrus ussuriensis Maximowicz (PFE) with two strains of lactic acid bacteria. The soluble solid content of the PFE was $5.25{ }^{\circ}$ Brix and it also displayed a high potassium content of $127.6 \mathrm{mg} / 100 \mathrm{~g}$. The first lactic acid fermentation of PFE was performed with Leuconostoc citreum $\mathrm{S} 5$ at $25^{\circ} \mathrm{C}$ for 2 days. Subsequently, the second lactic acid fermentation was caried out with the first fermented PFE fortified with $3 \%$ monosodium L-glutamate (MSG) by Lacobacillus plantarum EJ2014 at $30{ }^{\circ} \mathrm{C}$ for 5 days. During the first fermentation, the $\mathrm{pH}$ of the PFE medium decreased from 4.42 to 4.19 and the acidity increased from $0.28 \%$ to $1.03 \%$. After the second fermentation, $\mathrm{pH}$ was 4.64 and acidity was $1.23 \%$. The viable cell counts of $L$ c. citreum $\mathrm{S} 5$ and $L$. plantarum EJ2014 were $7.94 \log$ CFU $/ \mathrm{mL}$ and 9.18 $\log \mathrm{CFU} / \mathrm{mL}$, respectively. The amount of the reducing sugar in PFE increased during the first fermentation period and was nearly consumed during the $2^{\text {nd }}$ fermentation. Notably, MSG was successfully converted into $1.78 \%$ of GABA during the second fermentation. In conclusion, high yield for production of GABA was achieved by a novel mixed fermentation of lactic acid bacteria, which highlights PFE as a functional food material.
\end{abstract}

Key words : Pyrus ussuriensis Maximowicz, r-aminobutyric acid, lactic acid bacteria, monododium L-glutamate

\section{서 론}

젖산균은 우유 및 채소류의 발효에 관여하여 발효식품의 저장성과 풍미를 부여한다. 메치니코프에 의해 발효유의 젖산균들이 정장작용을 한다는 것과 불가리아 농민들의 장수비결이 발효유라는 것이 소개된 이후로 젖산균과 관련 된 건강을 위한 많은 연구들이 보고되고 있다(1,2). 그 중에 서도 Lactobacillus spp.는 대표적인 probiotic으로서 정장작 용, 면역증진 등의 효능이외에 최근 뇌건강과 관련된 효능

*Corresponding author. E-mail : splee@kmu.ac.kr

Phone : 82-53-580-5554, Fax : 82-53-580-6447

Received 09 July 2019; Revised 09 September 2019; Accepted 17 September 2019.

Copyright (c) The Korean Society of Food Preservation. All rights reserved.
이 보고되었다(3).

Lacotobacillus spp. 중에서도 Lactobacillus plantarum 균 주가 생성하는 8 -aminobutyric acid(GABA)는 산에 대한 내 성기작의 일환으로 생성되며 전구물질인 glutamate가 $\mathrm{GAD}$ (glutamate decarboxylase)에 의해 탈탄산화 되어 생성된다. $\mathrm{GABA}$ 는 자연계에 존재하는 비단백질 아미노산으로 포유 류의 중추신경계에서 흥분 억제성 신경전달물질로서 작용 하며, 항 정신불안증, 항 경련 효과가 있다(4,5). 또한 뇌세포 대사기능을 촉진시키며, 혈압강하 효과, 기억력 증진 효과, 수면유도 효과가 있다고 보고되었다 $(6,7)$. 반면, GABA가 부족할 경우 경련, 간질 등을 유발시키기도 하는 것으로 알려져있다(5).

섭취를 통해 $\mathrm{GABA}$ 의 생리 활성 효과를 기대하기 위해서 는 하루 50-200 mg을 섭취해야 한다(8). 그러나 천연물에 존재하는 $\mathrm{GABA}$ 의 함량은 몹시 미미하기 때문에 고농도의 
GABA를 생산하기 위한 연구가 활발히 진행되고 있다(9). 특히 유산균 발효를 통해 $\mathrm{GABA}$ 의 함량을 크게 증가시킨 연구들이 보고되어 있다. 이와 관련된 연구로는 김치유래 젖산균 Lacotobacillus sp.에 의한 GABA 생산(10), 카카오 추출물의 젖산균 발효를 통한 $\mathrm{GABA}$ 생산(11), 양송이 유래 젖산균에 의한 $\mathrm{GABA}$ 생산(12) 등이 있다.

한편, 돌배나무류(Pyrus spp.)는 장미과에 속하는 낙엽교 목으로, 그 열매는 식용뿐만 아니라 민간약으로 널리 사용 되어왔다. 돌배나무류는 돌배나무(P. pyrifolia (Burm. fil.) Nakai), 산돌배나무(P. ussuriensis Maximowicz), 백운배나 무(P. ussuriensis Maximowicz var. hakunensis), 남해배나무 (P. ussuriensis Maximowicz var. nankaiensis (Nakai) T. Lee), 청실배나무( $P$. ussuriensis Maximowicz var. ovoidea Rehder), 털산돌배나무( $P$. ussuriensis Maximowicz var. pubescens Nakaie) 등 종류가 다양하다(13).

그 중에서도 산돌배나무는 돌배나무와 함께 우리나라에 널리 분포하는 야생 배나무류 중 하나로(14), 산돌배 열매는 민간에서 한의학적으로 토사(吐鹓), 개선(疥癬), 해열(解熱) 등의 약재로 쓰여 왔으며(15), 예로부터 조상들이 즐겨먹는 과일의 한 종류로서 잘 알려져 왔다.

돌배나무류는 돌배나무 잎 추출물의 자외선 $\mathrm{B}$ 에 의해 손상된 피부세포에 대한 보호효과(16), 산돌배나무 잎 분획 물의 항암 및 항균활성(17), DPPH free radical 소거법을 이용한 산돌배 나무의 항산화 활성 화합물 분리(18)에 관한 연구 등이 보고되어 있으나 산돌배나무의 과실을 이용하여 식품 소재로서 활용하고자 하는 연구는 미미한 실정이다. 따라서 본 연구에서는 산돌배 과실을 고부가 가치 식품 소재로 개발하고자 두 가지 젖산 균주를 이용한 혼합발효를 통해 probiotic과 기능성 물질 GABA가 강화된 기능성 산돌 배 과실 발효물을 생산하고자 하였다.

\section{재료 및 방법}

재 료

본 연구에 원료로 사용된 건조 산돌배는 서현생약영농조 합(Chungnam, Korea)에서 구매하였다. 젖산 발효 시 탄소 원으로 사용된 설탕과 GABA 생성을 위한 전구물질로 사용 된 MSG는 CJ 제일제당줒(Incheon, Korea)에서 구입하였고, MRS broth는 Difco ${ }^{\mathrm{TM}}$ Lactobacilli MRS(Becton Dicknson and Company, Sparks, MD, USA) 제품을 사용하였다.

\section{Lactobacillus plantarum EJ2014 스타터 배양액 제조}

Lactobacillus plantarum EJ2014(L. plantarum EJ2014)는 미강(Rice mill, Uljin, Korea)으로부터 분리한 균주를 한국 미생물보존센터에 기탁한 후 분양받아 사용하였다 $\mathrm{KCCM}$ 11545P). 이 균주를 MRS agar plate에 $30^{\circ} \mathrm{C}, 24$ 시간 배양한
다음 멸균한 MRS broth 액체배지에 순수 배양된 $L$. plantarum EJ2014를 한 백금이 접종하여 $30^{\circ} \mathrm{C}$ 에서 24시간 동안 정치 배양하여 스타터로 사용하였다.

\section{Leuconostoc citreum S5 스타터 배양액 제조}

Leuconostoc citreum S5(Lc. citreum S5)는 김치로부터 분 리한 균주를 한국미생물보존센터에 기탁한 후 분양받아 사용하였다(KCCM 10778P). 이 균주를 sucrose를 포함함 agar plate(sucrose $2 \%$, yeast extract $0.5 \%$, tryptone $0.25 \%$, $\mathrm{K}_{2} \mathrm{HPO}_{4} 0.25 \%$ )에 $25^{\circ} \mathrm{C}, 24$ 시간 배양한 다음 멸균한 MRS broth 액체배지에 순수 배양된 Lc. citreum S5를 한 백금이 접종하여 $30^{\circ} \mathrm{C}$ 에서 24 시간 동안 정치 배양하여 스타터로 사용하였다.

\section{건조 산돌배 과실 추출물 제조}

건조 산돌배 과실의 9 배에 해당하는 양의 증류수를 첨가 한 후 건조 산돌배를 넣어 $100^{\circ} \mathrm{C}$ 에서 30 분간 용출시켰다. 침지시킨 건조 산돌배를 hand blender(HR 1673, Koninklijke Philips N.V. Co., Ltd., Amsterdam, Nederland)를 이용하여 분쇄한 후 거름망(80목)을 이용하여 씨와 껍질 등의 불용성 물질들을 제거하여 사용하였다.

\section{건조 산돌배 과실 열수 추출물의 고형분 함량 분석}

건조 산돌배 과실 추출물(P. ussuriensis Maximowicz fruit extract, $\mathrm{PFE}$ )의 고형분 함량은 상압 가열 건조법(19)을 이용 하여 수분 함량을 5 회 반복 측정한 후 그 평균값을 100 에서 제외한 값으로 산출하였다. 수분 함량은 시료 $3 \mathrm{~mL}$ 를 항량 된 칭량 접시에 담은 후 $105^{\circ} \mathrm{C}$ 건조기(HB-502n, Hanbaek scientific Co., Bucheon, Korea)에서 건조하여 항량된 무게 를 측정하였다.

\section{젖산균 혼합 발효물 제조}

영양성분으로 yeast extract $1 \%(\mathrm{v} / \mathrm{v})$, potassium phosphate $0.5 \%(\mathrm{v} / \mathrm{v})$ 를 동일하게 첨가였으며, sucrose를 $0,5 \%(\mathrm{v} / \mathrm{v})$ 로 달리하였다. $L c$ c citreum $\mathrm{S} 5$ 스타터를 $1 \%(\mathrm{v} / \mathrm{v})$ 접종하여 $25^{\circ} \mathrm{C}$ 에서 2일간 정치배양 하였다. 2 일간의 발효 후 L plantarum $\mathrm{EJ} 2014$ 발효가 진행되는 동안 $\mathrm{GABA}$ 를 생성하기 위해 MSG 3\%(v/v)를 추가하였다.

\section{$\mathrm{pH}$ 및 적정 산도 측정}

$\mathrm{PFE}$ 젖산균 혼합 발효물의 $\mathrm{pH}$ 는 시료 $1 \mathrm{~mL}$ 에 증류수 $9 \mathrm{~mL}$ 를 첨가하여 희석한 후 $\mathrm{pH}$ meter(SevenEasy, Mettler-Toledo AG, Schwerzenbach, Switzerland)를 이용하 여 측정하였다. 적정 산도는 $\mathrm{pH}$ 8.3에 도달할 때까지 0.1 $\mathrm{N} \mathrm{NaOH}$ 로 적정하여 그 소비량을 lactic acid 함량(\%, v/v)으 로 환산하여 산출하였다(20). 


\section{생균수 측정}

생균수는 10 배 희석법을 이용하여 PFE 혼합 발효물 100 $\mu \mathrm{L}$ 에 멸균 증류수 $900 \mu \mathrm{L}$ 첨가하여 $10^{4}, 10^{5}, 10^{6}$ 배로 희석한 것을 $\mathrm{MRS}$ agar plate에 $20 \mu \mathrm{L}$ 도말하였다. 그 후 $30^{\circ} \mathrm{C}$ 항온배 양기(HB-201MS-4, Hanbaek scientific Co., Bucheon, Korea) 에서 24시간 배양한 다음 측정하여 colony forming unit $(\mathrm{CFU}) / \mathrm{mL}$ 로 나타내었다.

\section{환원당 함량 측정}

PFE 혼합 발효물의 환원당 함량은 dinitrosalicylic acid (DNS)법(21)에 따라 측정하였으며, D-glucose(Sigma Aldrich, St. Louis, MO, USA)를 표준물질로 사용하였다. 일정한 농도로 희석한 시료를 $15,000 \mathrm{rpm}$ 에서 20 분 원심분 리(Centrifuge 5415R, Eppendorf, Hamburg, Germany)하여 분리한 상등액 $1 \mathrm{~mL}$ 에 DNS 시약 $3 \mathrm{~mL}$ 를 첨가하였다. 그 후 5 분간 $100^{\circ} \mathrm{C}$ 물에서 발색시키고 40 분간 암소에서 실온 으로 냉각한 후 $550 \mathrm{~nm}$ 에서 UV spectrophotometer (Ultrospec ${ }^{\circledR} 2100$ pro, Amersham Biosciences, Waltham, MA, USA)를 이용하여 흡광도를 측정하였다.

\section{총 폴리페놀 함량 측정}

총 폴리페놀 함량은 $\mathrm{AOAC}$ 법(22)에 의하여 측정하였으 며, gallic acid (Sigma Aldrich, St. Louis, MO, USA)를 표준 물질로 사용하였다. 추출물을 농도별로 희석한 용액 $60 \mu \mathrm{L}$ 에 2 배 희석 folin시약 $60 \mu \mathrm{L}$ 를 첨가하여 3분간 방치한 후, $10 \% \mathrm{Na}_{2} \mathrm{CO}_{3}$ 용액 $60 \mu \mathrm{L}$ 를 첨가하여 반응시킨 용액의 흡광 도를 microplate spectrophotometer(Epoch, Biotek Instruments, Winooski, VT, USA)로 $700 \mathrm{~nm}$ 에서 측정하였 다.

\section{총 플라보노이드 함량 측정}

총 플라보노이드는 Nieva Moreno 등의 방법(23)을 이용 하여 측정하였으며, quercetin(Sigma-Aldrich, St. Louis, MO, USA)를 표준물질로 사용하였다. 각 시료 추출물 $0.1 \mathrm{~mL}$ 와 $80 \%$ ethanol $0.9 \mathrm{~mL}$ 를 혼합한 혼합물 $0.5 \mathrm{~mL}$ 에 $10 \%$ aluminium nitrate $0.1 \mathrm{~mL}, 1 \mathrm{M}$ potassium acetate $0.1 \mathrm{~mL}$ 그리고 $80 \%$ ethanol $4.3 \mathrm{~mL}$ 를 가하여 실온에 40 분 방치한 뒤 microplate spectrophotometer(Epoch, Biotek Instruments, Winooski, VT, USA)로 $415 \mathrm{~nm}$ 에서 흡광도를 측정하였다.

\section{무기질 함량 분석}

무기질 분석은 식품공전(24)에 따라 수행하였으며, 습식 분해법에 따라 시험용액을 조제하였다. 시료를 회화하고 염산과 증류수를 넣고 용해한 뒤 $100 \mathrm{~mL}$ 메스플라스크에 여과하여 정용하였다. 정용한 용액을 inductively coupled plasma atomic emission spectrometer(ICP-MS, ELAN 9000, Perkin Elmer Inc., CA, USA)로 무기질 표준품
(AccuStandard, New haven, CT, USA)을 이용하여 정성 원 소를 정성·정량하였다. ICP-MS 분석 조건으로 plasma power는 $1.3 \mathrm{kw}$, nebulizer gas flow는 $0.8 \mathrm{~L} / \mathrm{min}$, plasma gas flow $15 \mathrm{~L} / \mathrm{min}$, auxiliary gas flow $0.2 \mathrm{~L} / \mathrm{min}$ 로 하였다.

\section{TLC를 이용한 GABA 및 glutamic acid 정성 분석}

Silica gel thin layer chromatography(TLC) plate는 $10 \times 20$ $\mathrm{cm}^{2}$ 로 잘라서 $\mathrm{MSG}$ 와 $\mathrm{GABA}$ 를 측정하였다. 발효물은 증류 수로 2 배 희석한 후 원심분리한 상등액을 sample로 사용하 였다. TLC plate의 아래에서 $15 \mathrm{~mm}$ 높이에 $10 \mathrm{~mm}$ 의 간격을 유지하며 점적한 후 건조하고 전개하였다. 전개는 n-butyl alcohol:acetic acid glacial:distilled water를 3:1:1(v/v)의 비율 로 혼합하여 4시간 포화시킨 전개용매를 이용하여 chamber $\left(30 \times 25 \times 10 \mathrm{~cm}^{3}\right)$ 에서 TLC plate의 상단이 $10-15 \mathrm{~mm}$ 남을 때까지 진행하였다. 전개가 끝난 TLC plate는 건조한 후 발색하였으며, $0.2 \%$ ninhydrin 용액을 발색시약으로 사용 하였다. $90^{\circ} \mathrm{C}$ 건조기(HB-502n, Hanbaek Scientific Co., Bucheon, Korea)에서 5-10분 동안 발색시킨 후 발효물의 $\mathrm{MSG}$ 와 $\mathrm{GABA}$ spot을 확인하였다. $\mathrm{MSG}$ 의 표준물질로 사 용된 glutamate와 GABA의 표준물질은 Sigma-Aldrich(St. Louis, MO, USA)에서 구입하였으며, $0.5 \%$ 로 사용하였다.

$\mathrm{HPLC}$ 를 이용한 GABA 및 glutamic acid 정량 분석

$\mathrm{GABA}$ 전환율을 확인하기 위한 유리 아미노산 함량 측정 은 건조시킨 시료를 phenylisothiocyanate(PITC)용액 $20 \mu \mathrm{L}$ (MeOH : $\mathrm{H}_{2} \mathrm{O}:$ TEA : $\left.\mathrm{PITC}=7: 1: 1: 1\right)$ 에 유도체화 시킨 뒤 상온에서 30 분간 반응 시켰다. 시료를 완전히 건조시킨 후 $200 \mu \mathrm{L}$ 의 A solvent로 녹이고 원심분리한 후 상등액을 0.45 $\mu \mathrm{m}$ syringe filter로 여과하고 $\mathrm{C}_{19}$ 컬럼(Nova-Pak, 4 um, $3.9 \times 300 \mathrm{~mm}$ )이 장착된 $\mathrm{HPLC}($ Agilent $1260, \mathrm{CA}, \mathrm{USA}$ )로 분석하였다. Column 온도는 $46^{\circ} \mathrm{C}$ 를 유지하였으며, 분석 용 매 $\mathrm{A}(140 \mathrm{mM}$ NaHAc, $0.15 \%$ TEA, 0.03\% EDTA, 6\% $\left.\mathrm{CH}_{3} \mathrm{CN}\right)$, 용매 $\mathrm{B}\left(60 \% \mathrm{CH}_{3} \mathrm{CN}, 0.015 \% \mathrm{EDTA}\right)$ 를 농도구배 (A 100\%, A 0\%, $23 \mathrm{~min}$ ) 조건에서 $1.0 \mathrm{~mL} / \mathrm{min}$ 속도로 흘리 면서 $245 \mathrm{~nm}$ 에서 detector(HP $1100 \mathrm{series}$ )로 측정하였다. 표준물질로 사용한 glutamate와 GABA는 TLC 정성 분석에 서 사용한 것과 같다.

\section{통계처리}

실험 결과는 Statistical Package for the Social Science (SPSS, Version 20.0, SPSS Inc., Chicago, IL, USA)를 이용하 여 평균과 표준편차 $(\operatorname{mean} \pm \mathrm{SD})$ 를 구하였으며, 각 집단 간 평균치 차이를 검증하기 위하여 one way-ANOVA 및 Duncan's test를 적용하였다. 결과에 대한 검증은 $\mathrm{p}<0.05$ 수준에서 검증하였다. 


\section{결과 및 고찰}

\section{건조 산돌배 과실 열수 추출물 분석}

$\mathrm{PFE}$ 의 분석 결과는 Table 1,2 와 같다. Shin 등(25)은 추출 조건을 각각 water, $50 \% \mathrm{EtOH}, 100 \% \mathrm{EtOH}$ 로 달리하여 약용식물을 추출한 결과 폴리페놀은 $100 \% \mathrm{EtOH}$ 에서, 플라 보노이드는 $50 \% \mathrm{EtOH}$ 에서 가장 높게 측정되었다고 보고 하였다. 이를 건조 산돌배 과실 열수 추출물을 분석한 본 결과와 비교했을 때, 산돌배의 폴리페놀 함량과 플라보노 이드 함량은 측정된 결과보다 더 높은 것으로 나타났다.

무기질 7종의 분석 결과, 칼륨이 $127.6 \mathrm{mg} / 100 \mathrm{~g}$ 으로 가장 높은 함량을 나타내었으며, $\operatorname{Lim}$ 등(26)은 칼륨의 섭취가 나트륨 흡수 저해의 효과가 있다고 보고한 바 있다. 다음으 로 인 $8.52 \mathrm{mg} / 100 \mathrm{~g}$, 소듐 $5.11 \mathrm{mg} / 100 \mathrm{~g}$, 마그네슘 4.78 $\mathrm{mg} / 100 \mathrm{~g}$, 칼슘 $3.51 \mathrm{mg} / 100 \mathrm{~g}$, 철 $0.23 \mathrm{mg} / 100 \mathrm{~g}$, 망간 $0.05 \mathrm{mg} / 100 \mathrm{~g}$ 순으로 함유하고 있는 것을 확인하였다.

Table 1. Proximate composition of PFE

\begin{tabular}{cc}
\hline Items & Value \\
\hline $\mathrm{pH}$ & 4.50 \\
Acidity $(\%)$ & 0.28 \\
Reducing sugar $(\%)$ & 1.43 \\
Soluble content $\left({ }^{\mathrm{Brix}}\right)$ & 5.25 \\
Polyphenol $(\mu \mathrm{g} / \mathrm{mL})$ & 400.41 \\
Flavonoid $(\mu \mathrm{g} / \mathrm{mL})$ & 29.50 \\
\hline
\end{tabular}

Table 2. Mineral contents of PFE

\begin{tabular}{cc}
\hline Items & Content $(\mathrm{mg} / 100 \mathrm{~g})$ \\
\hline Potassium & 127.62 \\
Phosphorus & 8.52 \\
Sodium & 5.11 \\
Magnesium & 4.78 \\
Calcium & 3.51 \\
Ferrum & 0.23 \\
Manganese & 0.05 \\
\hline
\end{tabular}

\section{$\mathrm{pH}$, 산도 및 생균수 변화}

Starter를 접종하기 전 희석하지 않은 $\mathrm{PFE}$ 의 생균수를 확인한 결과 $0.0 \log \mathrm{CFU} / \mathrm{mL}$ 로 나타났다. 따라서 $\mathrm{PFE}$ 가 살균된 상태라고 판단하고 실험을 진행하였다. 추출 $\mathrm{PFE}$ 의 L. plantarum EJ2014 단일 젖산 발효에서 영양성분으로 glucose $0-2 \%$, yeast extract $1 \%, \mathrm{GABA}$ 의 전구물질 $\mathrm{MSG}$ $3 \%$ 를 공급한 후 7일간 발효를 진행하였을 때 TLC를 통해 $\mathrm{MSG}$ 가 여전히 잔존하는 것을 확인하였다(Fig. 1). 따라서 Kwon 등(27)의 연구에서 Leuconostoc sp. 균주가 생성하는 고분자 점성 물질인 dextran이 혐기적인 조건을 만듦에 따 라 Lactobacillus sp.의 발효를 원활히 한다는 결과를 바탕으 로 1차 Lc. citreum S5발효를 2일간 진행하였다. 이후 MSG $3 \%$ 를 첨가하여 2차 L plantarum EJ2014 발효를 7일간 진행 하였다. 1 차 발효 시 dextran의 전구물질인 sucrose를 각각 $0,5 \%$ 로 달리 첨가하였으며, 그 외의 영양 성분인 yeast extract와 potassium phosphate는 각각 $1 \%, 0.5 \%$ 로 동일하게 첨가하였다.

$\mathrm{PFE}$ 의 초기 $\mathrm{pH}$ 는 각각 $\mathrm{pH} 4.47, \mathrm{pH}$ 4.42로 나타났으며 1 차 발효가 진행됨에 따라 $\mathrm{pH}$ 가 감소하여 발효 2 일 차에 각각 $\mathrm{pH} 4.33, \mathrm{pH}$ 4.19로 나타났다. 그 후 2차 발효 시 첨가한 중성 물질인 $\mathrm{MSG}$ 로 인해 $\mathrm{pH}$ 가 소폭 증가하여 각각 $\mathrm{pH}$ $4.99, \mathrm{pH} 4.71$ 로 나타났다. Sucrose $0 \%$ 조건의 경우 2 차 발효가 진행되는 동안 $\mathrm{pH}$ 가 유의적으로 증가하여 2차 발효 7 일 차에 $\mathrm{pH} 5.46$ 을 나타내었으며, sucrose 5\% 조건의 경우 2 차 발효 3일 차까지 $\mathrm{pH} 4.90$ 으로 증가한 후 감소하여 2차 발효 7일 차에 $\mathrm{pH}$ 4.50을 나타내었다. Lim과 Lee(28)는 미생 물에 의해 GABA가 생성될 때 $\mathrm{GAD}$ 효소에 의해 glutamate 가 decarboxylation되는 동시에 proton이 소비됨으로써 $\mathrm{GABA}$ 의 생성과 더불어 $\mathrm{pH}$ 를 높이는 것으로 보고하였다. 따라서 2차 젖산균 발효가 진행되면서 $\mathrm{pH}$ 가 증가하는 현상 은 L. plantarum에 의해 기질인 $\mathrm{MSG}$ 가 $\mathrm{GABA}$ 로 전환되었 기 때문인 것으로 사료되었다.

$\mathrm{PFE}$ 의 초기 산도는 각각 $0.26,0.28 \%$ 로 나타났으며, 1 차 발효가 진행됨에 따라 산이 생성되어 각각 $0.73,1.03 \%$ 를 나타내었다. 그 후 2 차 발효 1 일 차에 sucrose $0 \%$ 조건의 경우 유의적인 감소 후 큰 변화를 나타내지 않았으며 2 차 발효 7일 차에 $0.43 \%$ 를 나타내었다. 반면에 sucrose $5 \%$

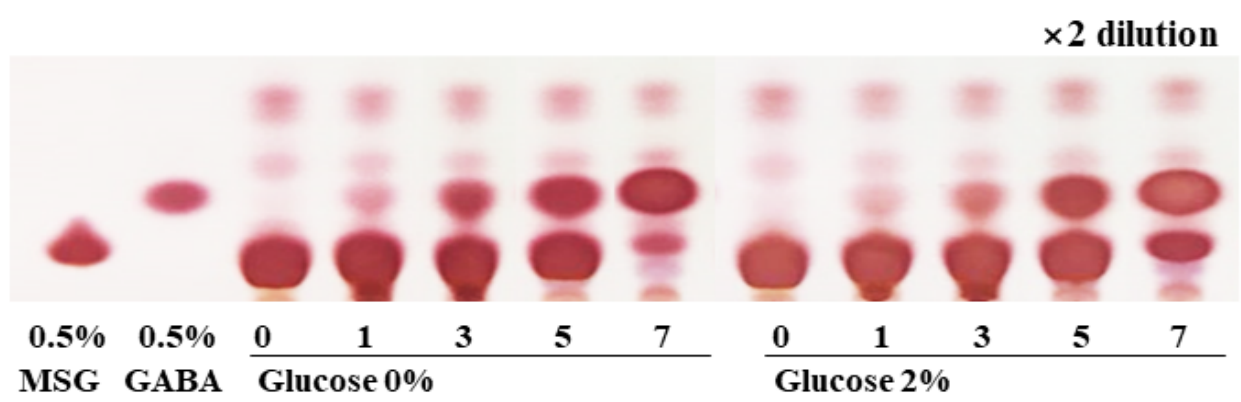

Fig. 1. TLC analysis of GABA in PFE fermented by L. plantarum EJ2014. 
조건의 경우 2 차 발효 1 일 차에 $1.28 \%$ 로 소폭 증가한 후 2 차 발효 3 일 차에 유의적으로 감소한 후 증가하여 2차 발효 7일 차에 $1.44 \%$ 로 나타났다(Fig. 2). 산도가 증가한 후 다시 감소한 것은 $\mathrm{pH}$ 의 변화와 마찬가지로 젖산균 발효 가 원활히 진행됨에 따라 유기산이 생성된 이후 전구물질인 glutamate가 GABA로 전환되는 과정에서 proton이 소비되 어 나타나는 현상이라고 판단하였다.

(A)

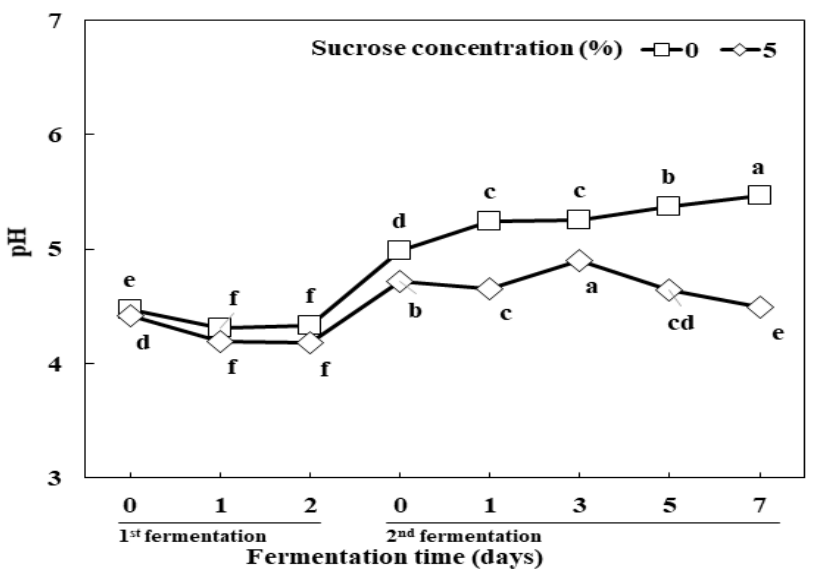

(B)

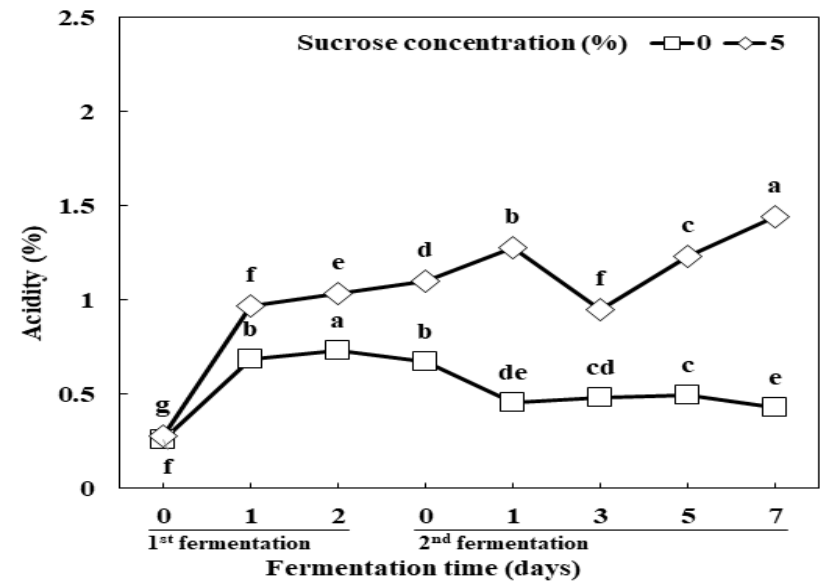

Fig. 2. Change in $\mathrm{pH}$ acidity of PFE co-fermented by $L c$. citreum S5 and L. plantarum EJ2014. (A) pH, (B) Acidity.

Each value is a mean \pm SD $(n=3)$. Different letters in the same condition mean significant difference by Duncan's multiple range test $(\mathrm{p}<0.05)$.

1 차 젖산 발효에 이용한 Lc. citreum S5의 생균수는 7.59 $\log \mathrm{CFU} / \mathrm{mL}$ 에서 1차 발효 2일 차에 각각 $8.75,8.87 \log$ $\mathrm{CFU} / \mathrm{mL}$ 로 증가하였다. 이후 2차 발효가 진행되면서 균수 가 전반적으로 감소하여, 2차 발효 7일 차에 $8.48,7.79 \log$ $\mathrm{CFU} / \mathrm{mL}$ 로 나타났다. 2 차 발효 시 L plantarum EJ2014 발효 를 위해 $7.46 \log \mathrm{CFU} / \mathrm{mL}$ 를 접종하였으며, sucrose $0,5 \%$ 두 조건 모두 2차 발효 5일 차에 9.07, $9.18 \log \mathrm{CFU} / \mathrm{mL}$ 로 증가한 후 2차 발효 7일 차에 미미하게 감소하였다(Fig.
3). 두 균주는 각 콜로니의 크기와 색깔을 비교하여 확인하 였다(Fig. 4).

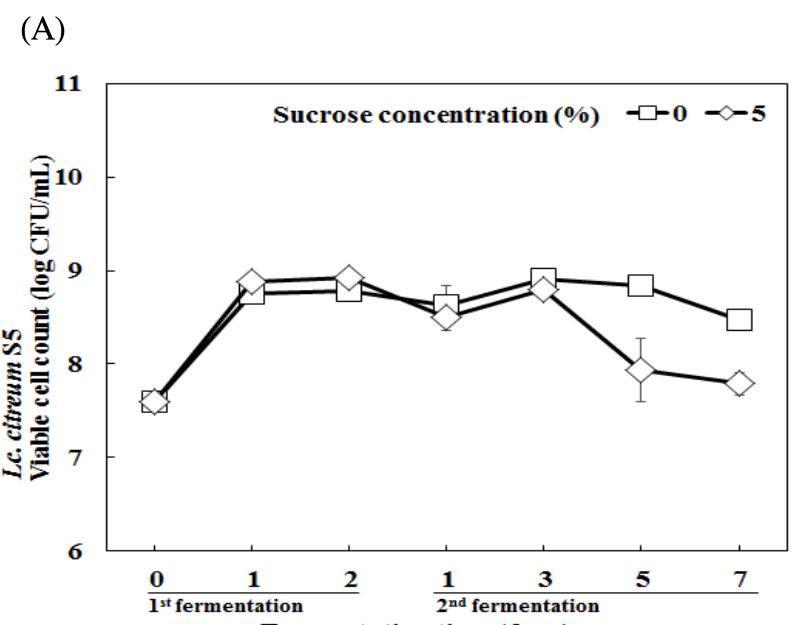

(B)

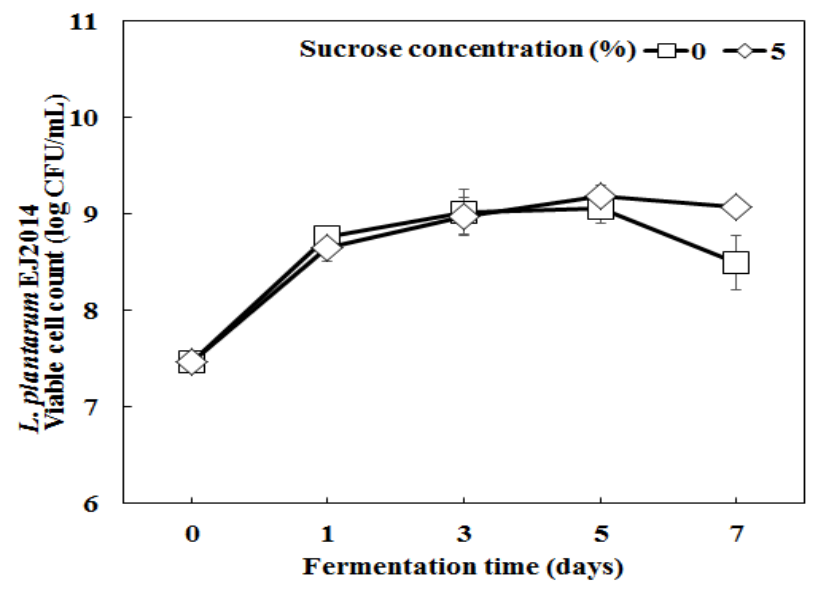

Fig. 3. Viable cell count of the PFE co-fermented by $L c$. citreum S5 and L. plantarum EJ2014. (A) Lc. citreum S5, (B) L. plantarum EJ2014.

Each value is a mean $\pm \mathrm{SD}(\mathrm{n}=3)$. Different letters in the same condition mean significant difference by Duncan's multiple range test $(\mathrm{p}<0.05)$.

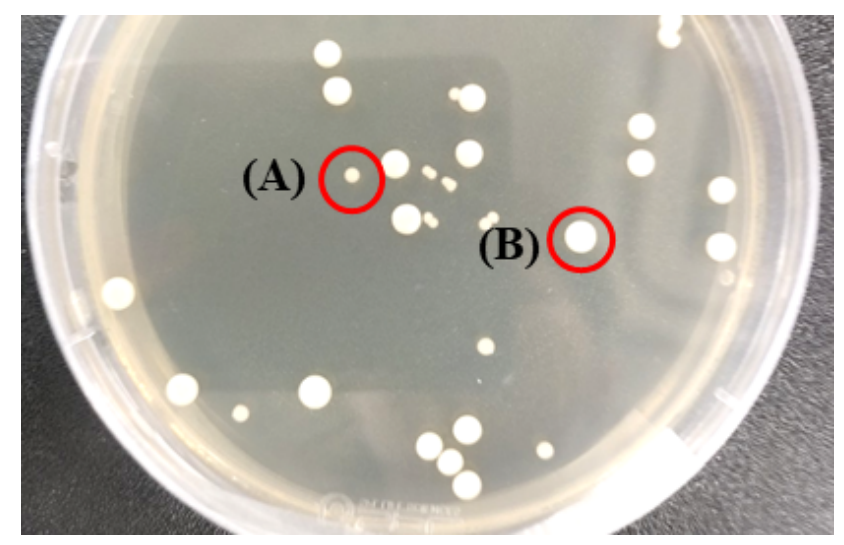

Fig. 4. Comparison of Lc. citreum S5 and L. plantarum EJ2014. (A) Lc. citreum S5, (B) L. plantarum EJ2014 


\section{환원당 함량 변화}

발효 초기 sucrose $0,5 \%$ 두 조건의 환원당은 $1.31,1.47 \%$ 로 나타났다. Sucrose $0 \%$ 조건의 경우 1 차 발효 1 일 차에 $0.11 \%$ 로 거의 모든 환원당을 소진하였다. Sucrose $5 \%$ 조건 의 경우 발효 1 일 차에 $1.71 \%$ 로 증가하였는데, 이는 Lee와 Park(29)의 연구결과에서 Leuconostoc sp.에 의해 sucrose가 glucose와 fructose로 분해된 것과 같이 비환원성 당인 sucrose가 분해되면서 환원성당인 glucose와 fructose로 전 환되었기 때문인 것으로 판단하였다. 1 차 발효 2 일 차에 $1.40 \%$ 로 감소하였으며 2차 발효 3 일 차까지 $0.29 \%$ 로 유의 적으로 감소하였다(Fig. 5). 1차 발효가 진행되는 동안 환원 당이 감소하는 것은 생성된 glucose와 fructose가 각각 dextran, mannitol로 합성, 전환(30) 되었기 때문인 것으로 판단하였다. 또한 2 차 발효가 진행되는 동안 환원당이 감소 하는 것은 L. plantarum EJ2014에 의해 환원당이 소진되었 기 때문인 것으로 판단하였으며, 이는 Song과 Park(31)의 연구결과와 일치하였다.

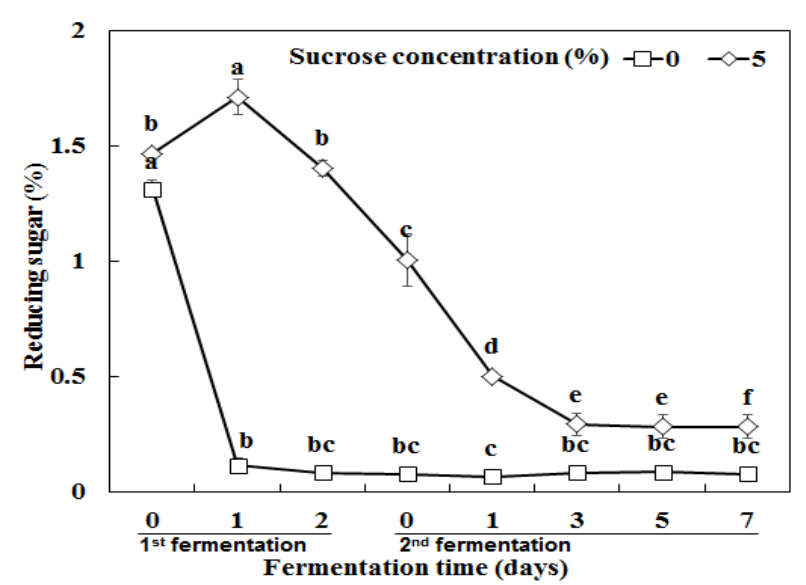

Fig. 5. Change in reducing sugar content of PFE co-fermented by Lc. citreum S5 and L. plantarum EJ 2014.

Each value is a mean $\pm \mathrm{SD}(\mathrm{n}=3)$. Different letters in the same condition mean significant difference by Duncan's multiple range test $(\mathrm{p}<0.05)$.

\section{$\mathrm{GABA}$ 생성능 및 $\mathrm{MSG}$ 소진능}

초기 sucrose 농도에 따른 젖산균 혼합 발효물의 $\mathrm{MSG}$ 소진과 GABA 생성을 비교하기 위해서 TLC plate를 이용하 여 확인한 결과 sucrose $0 \%$ 조건에서 2 차 발효 7 일 차에 $\mathrm{MSG}$ 가 잔존하는 것을 확인하였다. 반면 sucrose $5 \%$ 조건의 경우 2 차 발효 5 일 차에 거의 모든 $\mathrm{MSG}$ 가 소진되는 것을 확인하였다(Fig. 6). 따라서 sucrose $5 \%$ 를 첨가하여 2차 발 효를 5일간 진행하는 것이 GABA 생산에 있어서 최적조건 이라고 판단하였다. 이를 발효기간에 따른 환원당 함량변 화 결과와 비교했을 때, sucrose $0 \%$ 조건에서 sucrose $5 \%$ 조건과 달리 2 차 발효 초기에 거의 존재하지 않았던 환원당 함량이 MSG 소진과 GABA 생성에 영향을 끼쳤기 때문인 것으로 판단되었다. 따라서 초기 환원당의 농도는 MSG로 부터 $\mathrm{GABA}$ 를 생성할 때 매우 중요한 변수로 작용되는 것으로 판단되며, 이는 발효성 당이 부족할 경우 산 생성이 활발하지 않아 $\mathrm{GAD}$ 효소 활성이 떨어짐으로 인해 GABA 생산에 영향을 끼쳤다는 연구보고(32)와 유사한 경향을 나 타내었다.

최적조건으로 판단된 sucrose $5 \%$ 조건의 2 차 발효 5 일 차 sample의 glutamate와 GABA 함량을 HPLC를 이용하여 분석한 결과 $75.01 \mathrm{mg} / 100 \mathrm{~g}$ 의 glutamate가 잔존하고, $1780.77 \mathrm{mg} / 100 \mathrm{~g}$ 의 GABA가 생성된 것을 확인하였다 (Table 3).

Table 3. HPLC analysis of GABA in PFE co-fermented by $L c$. citreum S5 and L. plantarum EJ2014

\begin{tabular}{cc}
\hline & Content $(\mathrm{mg} / 100 \mathrm{~g})$ \\
\hline Glutamate & 75.01 \\
\hline GABA & 1780.77 \\
\hline
\end{tabular}

결론적으로 $\mathrm{PFE}$ 를 두 가지 젖산균으로 혼합발효하여 고 농도의 $\mathrm{GABA}$ 를 생산할 수 있었으며, 이는 식용으로 잘 활용되지 않는 산돌배 과실을 이용할 방법이 될 수 있다고

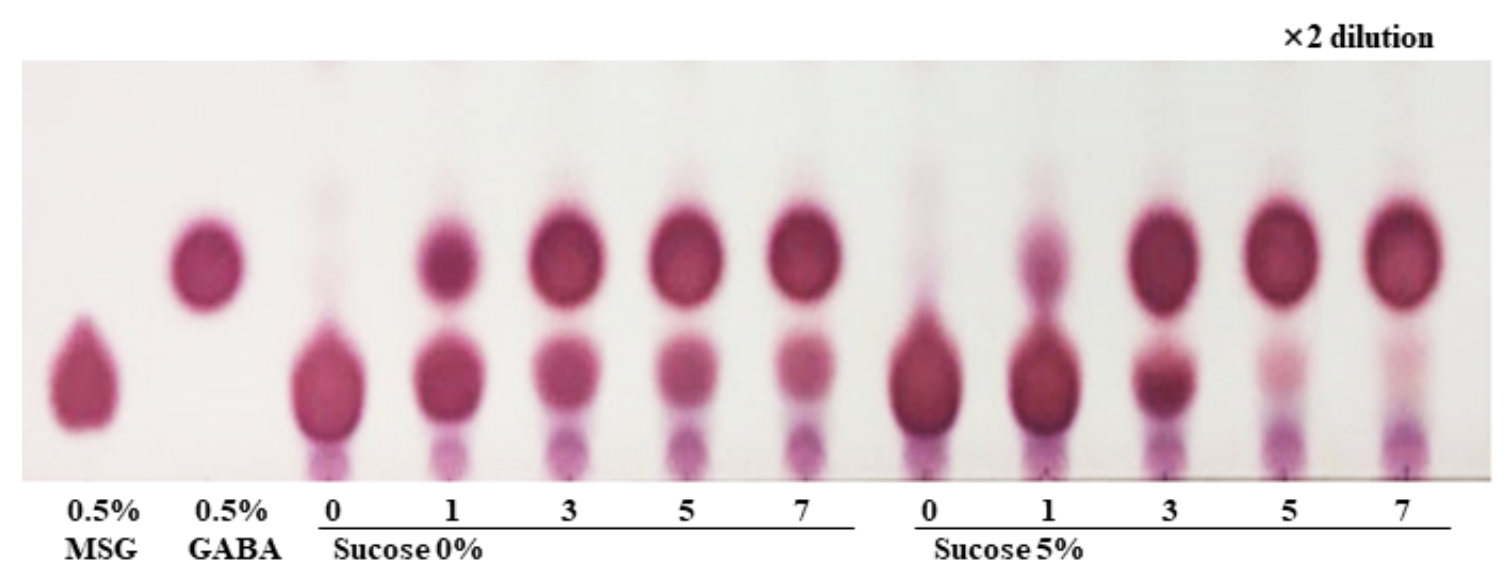

Fig. 6. TLC analysis of GABA in PFE co-fermented by Lc. citreum S5 and L. plantarum EJ 2014. 
사료된다. 또한 이 혼합발효물은 GABA, probotic 등이 함유 되어 기능성 식품 소재로의 이용 가능성이 높을 것으로 기대된다.

\section{요 약}

산돌배 추출액을 이용하여 젖산균 혼합발효를 통한 고농 도 GABA생산을 수행하였다. 산돌배 추출액은 수용성 고형 분함량 $5.25^{\circ} \mathrm{Brix}$, 다양한 무기질을 포함하여 높은 농도의 칼륨을 함유하였다. 1 차 젖산균 발효는 Leuc. citreum S5를 접종한 후 $25^{\circ} \mathrm{C}$ 에서 2 일 동안 정치 배양하였으며, 2 차 젖산 균 발효는 추가적으로 $3 \% \mathrm{MSG}$ 를 첨가하여 $30^{\circ} \mathrm{C}$ 에서 5 일 동안 정치 배양하였다. 1 차 젖산균 발효물은 $\mathrm{pH} 4.19,1.03 \%$ 산도를 보였으며, 2 차 L. plantarum 젖산균에 의한 혼합 발효물은 $\mathrm{pH} 4.50,1.44 \%$ 산도와 $9.07 \log \mathrm{CFU} / \mathrm{ml}$ 생균수를 나타내었다. 최종 산돌배 혼합 발효물은 환원당과 $\mathrm{MSG}$ 가 모두 소진되면서 $1.78 \% \mathrm{GABA}$ 를 포함하였다.

\section{감사의 글}

본 연구는 경상북도산림자원개발원에서 시행한 산림소 득식물개발연구 사업비로 수행하였음을 밝힙니다.

\section{References}

1. Park MS, Ji GE (2010) Research trends in Bifidobacterium. KSBB Journal, 25, 319-329

2. Cho YS, Chun SH, Lee KW (2018) Report on 'Bifidus' yogurt products in the Korean domestic market reflecting its regulated counting of bifidobacteria according to revised food code 2015. Food Sci Ind, 51, 72-80

3. Chang BY, Han JH, Cha BS, Ann SH, Kim SY (2015) Optimization of culture condition for enhancing the probiotics functions. J Food Hyg Saf, 30, 295-301

4. Fibiger HC, Lloyd KG (1984) Neurobiological substances of tardive dyskinesia, the GABA hypothesis. Trends Neursci, 7, 462-464

5. Kim SS, Oh SH, Jeong MH, Cho SC, Kook MC, Lee SH, Pyun YR, Lee HY (2010) Sleep-inductive effect of GABA on the fermentation of mono sodium glutamate (MSG). Korean J Food Sci Technol, 42, 142-146

6. Lee HH, Kim GH (2013) Changes in the levls of $\mathrm{\gamma}$ -aminobutyric acid and free amino acids during kimchi fermentation. Korean J Food Cookery Sci, 29, 671-677
7. Lee MJ, Kim SH, Kim HS, Kim HY, Seo WD, Choi SW, Lee KS, Jang KC (2018) Production of $\mathrm{\gamma}$ -aminobutyric acid using the Korean hull-less barley bran with clutamate. Korean J Crop Sci, 63, 35-40

8. Choi BY, Che SC (2015) Preparation of sun-dried salt containing GABA by co-crystallization of fermentation broth and deep sea water. Food Eng Prog, 19, 420-426

9. Bouche N, Fromm H (2004) GABA in plant: just a metabolite?. Trends Plant Sci, 9, 110-115

10. Yu JJ, Oh SH (2011) z-Aminobutyric acid production and glutamate decarboxylase activity of Lactobacillus sakei OPK2-59 isolated from Kimchi. Korean J Microbiol, 47, 316-322

11. Park YJ (2014) Study of anti-inflammatory efficacy of GABA enriched cacao fermentation by lactic acid bacteria. MS thesis, Kyunghee University, Korea, p 27-37

12. Lee YS, Song TY, Kong WS, Yoon MH (2013) Characterization of $\quad \gamma$-aminobutyric acid(GABA) produced by a lactic acid bacterium from button mushroom bed. J Mushroom Sci Prod, 11, 181-186

13. Jeong JG, Hwang SW, Song HJ, Shin MK (2004) A herbalogical study on the plants of rosaceae in korea. J Traditional Korean Med, 14, 119-153

14. Lee CE, Kim YH, Lee BG, Lee DH (2011) Anti-cancer and anti-microbial effect of the fraction isolated from Pyrus ussuriensis leaves. Jour Korean For Soc, 100, 136-141

15. Song JS, Ahn YH (2002) Phytosociological study on composition, distribution and habitat of the ussurian pear and chinese pear, Korean wild species. Kor J Env Eco, $16,160-171$

16. Koh AR, Choi SI, Kim YU, Park GH (2016) Protective effects of Pyrus pyrifolia NAKAI leaf extracts on UVB-induced toxicity in human dermal fibroblasts. J Soc Cosmet Sci Korea, 42, 87-94

17. Lee CE, Kim YH, Lee BG, Lee DH (2011) Anti-cancer and anti-microbial effect of the fraction isolated from Pyrus ussuriensis leaves. Jour Korean For Soc, 100, $136-141$

18. Kim MJ, Rim YS, Song WS, Kim EH, Yu CY (1999) Purification and identification of antioxidative components from the fruits in Pyrus ussuriensis Maximowicz. Korean J Medicinal Crop Sci, 7, 303-307

19. AOAC (1990) Official methods of analysis $15^{\text {th }}$ ed, Association of official analytical chemists. Washington DC, USA, $p 13$

20. AOAC (1990) Official methods of analysis $15^{\text {th }}$ ed, 
Association of official analytical chemists. Washington DC, USA, p 777-784

21. Miller GL (1959) Use of dinitrosalicylic acid reagent for determination of reducing sugar. Anal Chem, 31, 426-428

22. AOAC (1990) Official methods of analysis $15^{\text {th }} \mathrm{ed}$, Association of official analytical chemists. Washington DC, USA, p 1077-1918

23. Gao H, Kawabata J (2005) a-Glucosidase inhibition of 6-hydroxyflavones. Part 3: Synthesis and evaluation of 2,3,4-trihydroxybenzoyl- containing flavonoid analogs and 6-aminoflavones as a- glucosidase inbibitors. Bioorg Med Chem, 13, 1661-1671

24. Ministry of Food and Drug Safety. http://www. foodsafetykorea.go.kr/foodcode/01_03.jsp?idx=304(accesse d March 2019)

25. Shin JH, Kang JR, Kang MJ, Shin JH (2018) Physiological activity of five kinds of medicinal plant extracts with various solvents and their composites. J Life Sci, 28, 320-330

26. Lim HS, Ko YS, Shin DS, Heo YR, Chung HJ, Chae IS, Kim HY, Kim MH, Leem DG, Lee YK (2013) Sodium and potassium content of school meals for elementary and junior high school students in daegu, masan, gwangju, and jeju. J Korean Soc Food Sci Nutr, 42, 1303-1317
27. Kwon SY. Garcia CV, Song YC, Lee SP (2013) GABA-enriched water dropwort produced by co-fermentation with Leuconostoc mesenteroides SM and Lactobacillus plantarum K154. Korean J Food Sci Technol, 73, 233-238

28. Lim JS, Lee SP (2014) Production of set-type yogurt fortified with peptides and $\gamma$-aminovutyric acid by mixed fermentation using Bacillus subtilis and Lactococcus lactis. Korean J Food Sci Technol, 46, 165-172

29. Lee SH, Park YS (2017) Oligosaccharide production by Leuconostoc lactis CCK940 which has glucansucrase activity. Food Eng Prog, 21, 383-390

30. Hou DZ, Pu YY, Zou QS, Chen HL, Yu Y, Huang SX, Chen S (2018) Improvement of dextransucrase activity by glucose acclimation cultivation and kinetics of sucrose consumption. Sugar Tech, 20, 60-68

31. Song HN, Park MS (2018) Analysis of biological activities and functional components in fermented Gastrodia elata blume by Lactobacillus. J Korean Soc Food Sci Nutr, 47, 32-38

32. Lee EJ, Lee SP (2015) Optimization of $\gamma$-aminobutyric acid (GABA) production using immobilized lactobacillus plantarum $\mathrm{K} 154$ in submerged culture of ceriporia lacerata. Korean J Food Sci Technol, 47, 438-445 